\title{
UPAYA GURU DALAM MENINGKATKAN MOTIVASI BELAJAR SISWA
}

\author{
Siti Suprihatin \\ Pendidikan Ekonomi FKIP Universitas Muhammadiyah Metro \\ Sitisuprihatin43@yahoo.com
}

\begin{abstract}
Abstrak
Guru bagi masyarakat awan selama ini dipahami sebagai orang yang pekerjaannya mengajar. Pergeseran pengertian guru dari orang yang pekerjaannya mengajar menjadi pendidik profesional, tetapi bagi sebagian orang mungkin tidak begitu dimasalahkan. Guru memiliki pengaruh yang luar biasa bagi arah pengembangan pendidikan di Indonesia pergeseran pemahaman terhadap guru dari mengajar menjadi pendidik sudah menjadi keputusan hukum di Indonesia yang telah disahkan baik aturan tentang Guru dan Dosen. Hukum memberikan penjelasan guru sebagai pendidik profesional ketimbang sebagai orang yang pekerjaannya mengajar dengan kemampuan tenaga professional. Siswa akan terdorong untuk belajar manakala mereka memiliki motivasi untuk belajar. 1) Kuatnya kemauan untuk berbuat, 2) Jumlah waktu yang disediakan untuk belajar, 3) Kerelaan meninggalkan kewajiban atau tugas yang lain, 4) Ketekunan dalam mengerjakan tugas.

Menumbuhkan motivasi belajar siswa merupakan salah satu teknik dalam mengembangkan kemampuan dan kemauan belajar. Salah satu cara yang logis untuk momotivasi siswa dalam pembelajaran adalah mengaitkan pengalaman belajar dengan motivasi siswa. Guru sebagai orang yang membelajarkan siswa sangat berkepentingan dengan masalah ini. Sehingga sebagai guru atau calon guru sebisa mungkin kita harus selalu berupaya untuk dapat meningkatkan motivasi belajar terutama bagi siswa yang mengalami kesulitan dalam belajar dengan menggunakan berbagai upaya yang dapat dilakukan oleh guru yaitu 1) Memperjelas tujuan yang ingin dicapai. 2) Membangkitkan motivasi siswa. 3) Ciptakan suasana yang menyenangkan dalam belajar. 4) Mengguanakan variasi metode penyajian yang menarik. 5) Berilah pujian yang wajar setiap keberhasilan siswa. 6) Berikan penilaian. 7) Berilah komentar terhadap hasil pekerjaan siswa. 8) Ciptakan persaingan dan kerjasama.
\end{abstract}

Kata Kunci: Motivasi Belajar dan Upaya Guru.

\section{PENDAHULUAN}

Pendidikan adalah suatu bentuk investasi jangka panjang yang penting bagi seorang manusia. Pendidikan yang berhasil akan menciptakan manusia yang pantas dan berkelayakan di masyarakat serta tidak menyusahkan orang lain. Masyarakat dari yang paling terbelakang sampai yang paling maju mengakui bahwa pendidikan atau guru merupakan satu diantara sekian banyak unsur pembentuk utama calon anggota utama masyarakat. Pendidkan yang berhasil akan menciptakan manusia yang pantas dan berkelayakan di masyarakat sehingga menjadi penting pendidikan untuk mencetak manusia yang memiliki berkualitas dan berdaya saing. 
Guru dapat diibaratkan sebagai pembimbing perjalanan, yang berdasarkan pengetahuan dan pengalaman bertanggung jawab atas kelancaran perjalanan peserta didik dalam proses pembelajaran. Dalam proses pembelajaran peserta didik tentunya adanya beberapa hal yang mempengaruhi seperti motivasi, kematangan, hubungan peserta didik dengan guru, kemampuan verbal, rasa aman dan keterampilan guru dalam berkomunikasi atau berinteraksi dengan siswa menjadi faktor penting guru dalam proses pembelajaran. Dimana dalam proses belajar pada manusia dapat dirumuskan sebagai suatu aktivitas mental atau psikis yang berlangsung dalam interaksi aktif dengan lingkungan, yang menghasilkan perubahan-perubahan dalam pengetahuan dan nilai sikap. Perubahan itu bersifat relatif konstan dan berbekas. Sehingga guru mendai penting dalam proses pembelajaran peserta didik dalam berupaya mewujudkan perubahan sikap dan tingkah laku.

\section{PEMBAHASAN}

Seperti diketahui, motivasi belajar pada siswa tidak sama kuatnya, ada siswa yang motivasinya bersifat intrinsik dimana kemauan belajarnya lebih kuat dan tidak tergantung pada faktor di luar dirinya. Sebaliknya dengan siswa yang motivasi belajarnya bersifat ekstrinsik, kemauan untuk belajar sangat tergantung pada kondisi di luar dirinya. Namun demikian, di dalam kenyataan motivasi ekstrinsik inilah yang banyak terjadi, terutama pada anakanak dan remaja dalam proses belajar.

Proses pembelajaran akan berhasil manakala siswa mempunyai motivasi dalam belajar. Oleh karena itu, guru perlu menumbuhkan motivasi belajar siswa. Untuk memperoleh hasil belajar yang optimal, guru dituntut kreatif membangkitkan motivasi belajar siswa. Sebelum masuk kepada bagimana upaya seorang guru dalam memotivasi belajar siswa penulis terlebih dahulu akan membahas tentang apa itu motivasi, yang akan dilanjutkan dengan hal-hal yang perlu dilakukan oleh guru dalam memotivasi belajar siswa, ciri-ciri siswa termotivasi dan fugsi motivasi bagi siswa.

\section{Motivasi Belajar}

Sudarwan (2002:2) motivasi diartikan sebagai kekuatan, dorongan, kebutuhan, semangat, tekanan, atau mekanisme psikologis yang mendorong seseorang atau sekelompok orang untuk mencapai prestasi tertentu sesuai dengan apa yang dikehendakinya. Hakim (2007:26) mengemukakan pengertian motivasi adalah suatu dorongan kehendak yang menyebabkan seseorang melakukan suatu perbuatan untuk mencapai tujuan tertentu.

Huitt,W. (2001) mengatakan motivasi adalah suatu kondisi atau status internal (kadang-kadang diartikan sebagai 
kebutuhan, keinginan, atau hasrat) yang mengarahkan perilaku seseorang untuk aktif bertindak dalam rangka mencapai suatu tujuan. Ditambahkan Gray (Winardi, 2002) mengemukakan bahwa motivasi merupakan sejumlah proses, yang bersifat internal atau eksternal bagi seorang individu, yang menyebabkan timbulnya sikap antusiasme dan persistensi, dalam hal melaksanakan kegiatan- kegiatan tertentu.

Menurut Handoko (1992: 59), untuk mengetahui kekuatan motivasi belajar siswa, dapat dilihat dari beberapa indicator sebagai berikut :

a) Kuatnya kemauan untuk berbuat

b) Jumlah waktu yang disediakan untuk belajar

c) Kerelaan meninggalkan kewajiban atau tugas yang lain

d) Ketekunan dalam mengerjakan tugas.

Sedangkan menurut Sardiman (2001:81) motivasi belajar memiliki indikator sebagai berikut:

a) Tekun menghadapi tugas.

b) Ulet menghadapi kesulitan (tidak lekas putus asa)

c) Menunjukan minat terhadap bermacam-macam masalah orang dewasa.

d) Lebih senag bekerja mandiri

e) Cepat bosan pada tugas rutin

f) Dapat mempertahankan pendapatnya
Berdasarkan beberapa pendapat di atas, motivasi dapat diartikan sebagai kekuatan (energi) seseorang yang dapat menimbulkan tingkat kemauan dalam melaksanakan suatu kegiatan. Kemauan baik yang bersumber dari dalam diri individu itu sendiri (motivasi intrinsik) maupun dari luar individu (motivasi ekstrinsik). Seberapa kuat motivasi yang dimiliki individu akan banyak menentukan kualitas perilaku yang ditampilkannya, baik dalam konteks belajar, bekerja maupun dalam kehidupan lainnya.

\section{Upaya Meningkatkan Motivasi Belajar}

Upaya meningkatkan motivasi belajar anak dalam kegiatan belajar di sekolah, ada beberapa langkah yang dapat dilakukan oleh guru diungkapkan Sardiman (2005:92), yaitu:

a) Memberi angka Angka dalam hal ini sebagai simbol dari nilai kegiatan belajarnya. Banyak siswa yang justru untuk mencapai angka/nilai yang baik. Sehingga yang dikejar hanyalah nilai ulangan atau nilai raport yang baik. Angka-angka yang baik itu bagi para siswa merupakan motivasi yang sangat kuat. Yang perlu diingat oleh guru, bahwa pencapaian angka-angka tersebut belum merupakan hasil belajar yang sejati dan bermakna. Harapannya angka-angka tersebut dikaitkan dengan 
nilai afeksinya bukan sekedar kognitifnya saja.

b) Hadiah dapat menjadi motivasi yang kuat, dimana siswa tertarik pada bidang tertentu yang akan diberikan hadiah. Tidak demikian jika hadiah diberikan untuk suatu pekerjaan yang tidak menarik menurut siswa.

c) Kompetisi Persaingan, baik yang individu atau kelompok, dapat menjadi sarana untuk meningkatkan motivasi belajar. Karena terkadang jika ada saingan, siswa akan menjadi lebih bersemangat dalam mencapai hasil yang terbaik.

d) Ego-involvement Menumbuhkan kesadaran kepada siswa agar merasakan pentingnya tugas dan menerimanya sebagai tantangan sehingga bekerja keras adalah sebagai salah satu bentuk motivasi yang cukup penting. Bentuk kerja keras siswa dapat terlibat secara kognitif yaitu dengan mencari cara untuk dapat meningkatkan motivasi.

e) Memberi Ulangan Para siswa akan giat belajar kalau mengetahui akan diadakan ulangan. Tetapi ulangan jangan terlalu sering dilakukan karena akan membosankan dan akan jadi rutinitas belaka.

f) Mengetahui Hasil Mengetahui hasil belajar bisa dijadikan sebagai alat motivasi. Dengan mengetahui hasil belajarnya, siswa akan terdorong untuk belajar lebih giat. Apalagi jika hasil belajar itu mengalami kemajuan, siswa pasti akan berusaha mempertahankannya atau bahkan termotivasi untuk dapat meningkatkannya.

g) Pujian Apabila ada siswa yang berhasil menyelesaikan tugasnya dengan baik, maka perlu diberikan pujian. Pujian adalah bentuk reinforcement yang positif dan memberikan motivasi yang baik bagi siswa. Pemberiannya juga harus pada waktu yang tepat, sehingga akan memupuk suasana yang menyenangkan dan mempertinggi motivasiÂ belajar serta sekaligus akan membangkitkan harga diri.

h) Hukuman Hukuman adalah bentuk reinforcement yang negatif, tetapi jika diberikan secara tepat dan bijaksana, bisa menjadi alat motivasi. Oleh karena itu, guru harus memahami prinsipprinsip pemberian hukuman tersebut.

Dalam rangka mengupayakan agar motivasi belajar siswa tinggi, seorang guru menurut Winkel (1991) hendaknya selalu memperhatikan hal-hal sebagai berikut :

a) Seorang guru hendaknya mampu mengoptimalisasikan penerapan prinsip belajar, pada prinsipnya harus memandang bahwa dengan kehadiran siswa di kelas merupakan suatu 
motivasi belajar yang datang dari siswa.

b) Guru hendaknya mampu mengoptimalisasikan unsur-unsur dinamis dalam pembelajaran, karena dalam proses belajar, seorang siswa terkadang dapat terhambat oleh adanya berbagai permasalahan. Hal ini dapat disebabkan oleh karena kelelahan jasmani ataupun mental siswa, sehingga seorang guru harus berupaya untuk membangkitkan kembali kinginan siswa dalam belajar. Upaya yang dapat dilakukan oleh seorang guru menurut Dimyati (2002:95) yaitu dengan cara :

1) Memberi kesempatan kepada siswa untuk mengungkapkan hambatan belajar yang di alaminya ;

2) Meminta kesempatan kepada orang tua siswa agar memberikan kesempatan kepada siswa untuk beraktualisasi diri dalam belajar.

3) Memanfaatkan unsur-unsur lingkungan yang mendorong belajar.

4) Menggunakan waktu secara tertib, penguat dan suasana gembira terpusat pada perilaku belajar.

5) Merangsang siswa dengan penguat memberi rasa percaya diri bahwa ia dapat mengatasi segala hambatan dan pasti berhasil.

6) Guru mengoptimalisasikan pemanfataan pengalaman dan kemampuan siswa. Perilaku belajar yang ditunjukkan siswa merupakan suatu rangkaian perilaku yang ditunjukkan pada kesehariannya. Untuk itu, maka pengalaman yang diberikan oleh guru terhadap siswa dalam meningkatkan motivasi belajar menurut Dimyati (2002) adalah dengan cara :

i) siswa ditugasi membaca bahan belajar sebelumnya, tiap membaca hal-hal penting dari bahan tersebut dicatat.

ii) guru memecahkan hal yang sukar bagi siswa dengan cara memecahkannya.

iii) guru mengajarkan cara memecahkan dan mendidik keberanian kepada siswa dalam mengatasi kesukaran.

iv) guru mengajak serta siswa mengalami dan mengatasi kesukaran.

v) guru memberi kesempatan kepada siswa untuk mampu memecahkan masalah dan mungkin akan membantu rekannya yang mengalami kesulitan.

vi) guru memberi penguatan kepada siswa yang berhasil mengatasi kesulitan belajarnya sendiri. 
vii) guru menghargai pengalaman dan kemampuan siswa agar belajar secara mandiri.

Faktor-faktor yang mempengaruhi motivasi berprestasi (Sukadi,2006) mengatakan bahwa ada beberapa faktor yang mempengaruhi motivasi berprestasi, yaitu sebagai berikut:

a) Pengalaman pada tahun-tahun pertama kehidupan

Adanya perbedaan pengalaman masa lalu pada setiap orang menyebabkan terjadinya variasi terhadap tinggi rendahnya kecenderungan untuk berprestasi pada diri seseorang.

b) Latar belakang budaya tempat seseorang dibesarkan

Bila dibesarkan dalam budaya yang menekankan pada pentingnya keuletan, kerja keras, sikap inisiatif dan kompetitif, serta suasana yang selalu mendorong individu untuk memecahkan masalah secara mandiri tanpa dihantui perasaan takut gagal, maka dalam diri seseorang akan berkembang hasrat berprestasi yang tinggi.

c) Peniruan tingkah laku (Modelling)

Melalui modelling, anak mengambil atau meniru banyak karakteristik dari model, termasuk dalam kebutuhan untuk berprestasi jika model tersebut memiliki motivasi tersebut dalam derajat tertentu. d) Lingkungan tempat proses pembelajaran berlangsung

Iklim belajar yang menyenangkan, tidak mengancam, memberi semangat dan sikap optimisme bagi siswa dalam belajar, cenderung akan mendorong seseorang untuk tertarik belajar, memiliki toleransi terhadap suasana kompetisi dan tidak khawatir akan kegagalan.

e) Harapan orangtua terhadap anaknya Orangtua yang mengharapkan anaknya bekerja keras dan berjuang untuk mencapai sukses akan mendorong anak tersebut untuk bertingkahlaku yang mengarah kepada pencapaian prestasi.

Selain beberapa pendapat di atas menurut Sanjaya, (2009) ada beberapa hal yang perlu dilakukan oleh seorang guru untuk meningkatkan motivasi belajar siswa, yaitu sebagai berikut:

a) Memperjelas tujuan yang ingin dicapai. Tujuan yang jelas dapat membuat siswa paham kearah mana ia ingin dibawa. Pemahaman siswa terhadap tujuan pembelajaran dapat menumbuhkan minat siswa untuk belajar yang pada gilirannya dapat meningkatkan motivasi belajar mereka. Semakin jelas tujuan yang ingin dicapai, maka akan semakin kuat motivasi nbelajar siswa (Sanjaya, 2009:29).

b) Membangkitkan motivasi siswa 
Siswa akan terdorong untuk belajar manakala mereka memiliki minat untuk belajar. Oleh karena itu, mengembangkan minat belajar siswa merupakan salah satu teknik dalam mengembangkan motivasi belajar (Sanjaya, 2009:29). Salah satu cara yang logis untuk momotivasi siswa dalam pembelajaran adalah mengaitkan pengalaman belajar dengan minat siswa (Djiwandono, 2006:365).

c) Ciptakan suasana yang menyenangkan dalam belajar

Siswa hanya mungkin dapat belajar baik manakala ada dalam suasana yang menyenangkan, merasa aman, bebas dari takut. Usahakan agar kelas selamanya dalam suasana hidup dan segar, terbebas dari rasa tegang. Untuk itu guru sekali-kali dapat melakukan hal-hal yang lucu.

d) Mengguanakan variasi metode penyajian yang menarik

Guru harus mampu menyajikan informasi dengan menarik, dan asing bagi siswa-siswa. Sesuatu informasi yang disampaikan dengan teknik yang baru, dengan kemasan yang bagus didukung oleh alat-alat berupa sarana atau media yang belum pernah dikenal oleh siswa sebelumnya sehingga menarik perhatian bagi mereka untuk belajar (Yamin,2009:174). Dengan pembelajaran yang menarik, maka akan membangitkan rasa uingin tahu siswa di dalam kegiatan pembelajaran yang selanjutnya siswa akan termotivasi dalam pembelajaran.

e) Berilah pujian yang wajar setiap keberhasilan siswa

Motivasi akan tumbuh manakala siswa merasa dihargai. Dalam pembelajaran, pujian dapat dimanfaatkan sebagai alat motivasi. Karena anak didik juga manusia, maka dia juga senang dipuji. Karena pujian menimbulkan rasa puas dan senang (Sanjaya, 2009:30) Namun begitu, pujian harus sesuai dengan hasil kerja siswa. Jangan memuji secara berlebihan karena akan terkesan dibuatbuat. Pujian yang baik adalah pujian yang keluar dari hati seoarang guru secara wajar dengan maksud untuk memberikan penghargaan kepada siswa atas jerih payahnya dalam belajar (Djamarah, 2002:152).

\section{f) Berikan penilaian}

Banyak siswa yang belajar karena ingin memperoleh nilai bagus. Untuk itu mereka belajar dengan giat. Bagi sebagian siswa nilai dapat menjadi motivasi yang kuat untuk belajar. Oleh karena itu, penilaian harus dilakukan dengan segera agar siswa secepat mungkin mengetahui hasil kerjanya. Penilaian harus dilakukan secara objektif sesuai dengan kemampuan siswa masing-masing (Sanjaya, 
2009:31). Penilaian secara terus menerus akan mendorong siswa belajar, oleh karena setiap anak memilki kecenderungan untuk memmperoleh hasil yang baik. Disamping itu, para siswa selalu mendapat tantangan dan masalah yang harus dihadapi dan dipecahkan, sehingga mendorongnya belajar lebih teliti dan seksama (Hamalik, 2009:168).

g) Berilah komentar terhadap hasil pekerjaan siswa

Penghargaan bisa dilakukan dengan mmemberikan komentar yang positif. Setelah siswa selesai mengerjakan suatu tugas, sebaiknya berikan komentar secepatnya, misalnya dengan memberikan tulisan " bagus" atau "teruskan pekerjaanmu" dan lain sebagainya. Komentar yang positif dapat meningkatkan motivasi belajar siswa (Sanjaya, 2009:21).

h) Ciptakan persaingan dan kerjasama Persaingan yang sehat dapat menumbuhkan pengaruh yang baik untuk keberhasilan proses pemebelajaran siswa. Melalui persaingan siswa dimungkinkan berusaha dengan sungguh-sungguh untuk memperoleh hasil yang terbaik (Sanjaya, 2009:31). Oleh sebab itu, guru harus mendesain pembelajaran yang memungkinkan siswa untuk bersaing baik antar kelompok maupun antar individu.

Proses pembelajaran akan berhasil manakala siswa mempunyai motivasi dalam belajar. Oleh karena itu, guru perlu menumbuhkan motivasi belajar siswa. Untuk memperoleh hasil belajar yang optimal, guru dituntut kreatif membangkitkan motivasi belajar siswa. Berikut ini dikemukakan beberapa petunjuk untuk meningkatkan motivasi belajar siswa.

\section{Ciri Siswa Bermotivasi Tinggi}

Menurut Sardiman (1996) siswa yang memiliki motivasi tinggi memiliki beberapa ciri-ciri, antara lain sebagai berikut:

a) Tekun menghadapi tugas

b) Ulet menghadapi kesulitan/tidak cepat putus asa.

c) Tidak memerlukan dorongan dari luar untuk berprestasi sebaik mungkin.

d) Lebih senang kerja mandiri.

e) Cepat bosan pada tugas-tugas yang rutin.

f) Dapat memperthanankan pendapatnya .

g) Tidak mudah melepaskan hal yang sudah diyakininya.

\section{Fungsi Motivasi}

Motivasi mempunyai fungsi yang penting dalam belajar, karena motivasi akan menentukan intensitas usaha belajar yang dilakukan siswa. Sardiman (1996:84) mengemukakan ada tiga fungsi motivasi, yaitu: 
a) Mendorong manusia untuk berbuat. Motivasi dalam hal ini merupakan motor penggerak dari setiap kegiatan yang akan dikerjakan.

b) Menuntun arah perbuatan, yakni ke arah tujuan yang hendak dicapai, dengan demikian motivasi dapat memberi arah, dan kegiatan yang harus dikerjakan sesuai dengan rumusan tujuannya.

c) Menyeleksi perbuatan, yakni menentukan perbuatan-perbuatan apa yang harus dikerjakan yang serasi guna mencapai tujuan, dengan menyisihkan perbuatan-perbuatan yang tidak bermanfaat bagi tujuan tersebut.

Motivasi diperlukan dalam menentukan intensitas usaha belajar bagi para siswa. Menurut Djamarah (2002:123) ada tiga fungsi motivasi, yakni :

a) Motivasi sebagai pendorong perbuatan. Motivasi berfungsi sebagai pendorong untuk mempengaruhi sikap apa yang seharusnya anak didik ambil dalam rangka belajar.

b) Motivasi sebagai penggerak perbuatan. Dorongan psikologis melahirkan sikap terhadap anak didik itu merupakan suatu kekuatan yang tak terbendung,yang kemudian terjelma dalam bentuk gerakan psikofisik.

c) Motivasi sebagai pengarah perbuatan. Anak didik yang mempunyai motivasi dapat menyeleksi mana perbuatan yang harus dilakukan dan perbuatan yang perlu diabaikan.

\section{KESIMPULAN}

Motivasi dapat diartikan sebagai kekuatan seseorang yang dapat menimbulkan tingkat kemauan dalam melaksanakan suatu kegiatan. Kemauan baik yang bersumber dari dalam diri individu itu sendiri (motivasi intrinsik) maupun dari luar individu (motivasi ekstrinsik). Seberapa kuat motivasi yang dimiliki individu akan banyak menentukan kualitas perilaku yang ditampilkannya, baik dalam konteks belajar, bekerja maupun dalam kehidupan lainnya.

Proses pembelajaran akan berhasil manakala siswa mempunyai motivasi dalam belajar. Oleh karena itu, guru perlu menumbuhkan motivasi belajar siswa. Untuk memperoleh hasil belajar yang optimal, guru dituntut kreatif membangkitkan motivasi belajar siswa. karena dengan guru kratif menjadikan siswa tergugah dalam pembelajaran yang akan dialami siswa atau siswa yang sedang mengikuti proses pembelajaran.

\section{DAFTAR PUSTAKA}

Damin, Sudarman. (2004). Inovasi Pedididkan. Bandung: Pustaka Setia

Djamarah. 2002. Strategi Belajar Mengajar. Jakarta : Rineka Cipta. 
Dimyati, Mudjiono. 2002. Belajar dan Pembelajaran. Jakarta: Rineka Cipta

Hamalik. 2009. Proses Belajar Mengajar. Bandung : Bumi Aksara.

H. Martinis, Yamin. 2009. Srategi Pembelajaran Berbasis Kompetensi. Jakarta : Gaung Persada

Handoko, T. Hani, 1992. Manajemen personal dan sumber daya manusia, edisi kedua, cetak ke empat. Penerbit yogyakarta: UGM

Sukadi, (2006)Guru Powerful Guru Masa Depan. Bandung

Sanjaya, Wina. 2009. Strategi Pembelajaran Berorientasi Standar Proses Pendidikan. Jakarta : Kencana Prenada Media Group

Sardiman, AM.1996. Interaksi dan Motivasi Belajar Mengajar Pedoman bagi Guru dan Calon Guru. Jakarta: Rajawali Pers.

Sardiman,A.M. 2001. Interaksi dan Motivasi Belajar Mengajar. Jakarta: Grafindo.

Sardirman, A.M. 2005. Interaksi dan Motivasi Belajar Mengajar. Jakarta: Grafindo.

Oemar, Hamalik (2007). Proses Belajar. Jakarta: Buki Aksara.

Winkel, W.S, 1991. Bimbingan dan Konseling di Sekolah Menengah: PT. Grasindo. Jakarta.

Wuitt,W.(2001). Motivation To Learn. An Overview. Educational Psychology Interactive. Valdosta: Saldosta State University. 